\title{
Bismuth-Containing Therapy for Helicobacter pylori Eradication
}

\section{Huei-Mi Li ${ }^{1}$, Jyh-Chin Yang ${ }^{2 *}$}

${ }^{1}$ School of Pharmacy, National Taiwan University, Taipei, Taiwan

${ }^{2}$ Department of Internal Medicine, Hospital and College of Medicine, National Taiwan University, Taipei, Taiwan

\section{Introduction}

Helicobacter pylori (H. pylori) was first identified in human and cultured by Marshall and Warren in 1982 [1]. More than $50 \%$ of the world's population are infected by $H$. pylori, which is etiologically associated with gastritis, gastric atrophy, peptic ulcer, mucosaassociated lymphoid tissue (MALT) lymphoma and gastric cancer $[2,3]$. Currently, triple therapy with combinations of a proton pump inhibitor (PPI) and two antibiotics (i.e., PPIs/clarithromycin/ amoxicillin or metronidazole) are used as the treatment of choice for $H$. pylori infection [4-6]. However, resistance to antibiotics can be the major factor affecting the cure rate for $H$. pylori infection [7]. The prevalence of resistance to clarithromycin or metronidazole in different studies has been variously reported to be $2-25 \%$ or $9-76 \%$, respectively, depending on the geographical areas, and the trend to antibiotic resistance is rising [8-12]. Consequently, the eradication rate of triple therapy for $H$. pylori infection has been rapidly falling to below $80 \%$ in most areas $[13,14]$. This increase in antibiotic resistance has become a challenge to the eradication of $H$. pylori and alternative treatments are required.

\section{Publication History:}

Received: May 05, 2015

Accepted: July 02, 2016

Published: July 04, 2016

\section{Keywords:}

Phytotherapy, Natural anxiolytics, Active plant compounds, GABAA receptors

the development of antibiotic resistance [17-19], further limiting the efficacy of subsequent rescue therapies. These recommended treatments were summarized in Table 1.

Compared to clarithromycin, not only resistance to bismuth has not been reported but resistance to tetracycline is also uncommon, with a mean rate of $1-10 \%[9,20,21]$. The aim of the present work is to briefly review the development of bismuth-containing therapy for H. pylori infection.

\begin{tabular}{|c|c|c|c|c|}
\hline Guidelines & $\begin{array}{l}2016 \\
\text { Canada }\end{array}$ & $\begin{array}{l}2012 \\
\text { Europe }\end{array}$ & $\begin{array}{l}2009 \\
\text { Asia-Pacific Region }\end{array}$ & $\begin{array}{l}2007 \\
\text { USA }\end{array}$ \\
\hline First-line & $\begin{array}{l}\text { Guided by antimicrobial } \\
\text { susceptibility testing } \\
\text { BQT, } 14 \text { days } \\
\text { CT, } 14 \text { days }\end{array}$ & $\begin{array}{l}\text { Low CLA-R } \\
\text { CLA-TT, 7-14 days } \\
\text { High CLA-R } \\
\text { BQT, 10-14 days }\end{array}$ & CLA-TT, 7-14 days & $\begin{array}{l}\text { CLA-TT, } 10-14 \text { days } \\
\text { BQT, 10-14 days }\end{array}$ \\
\hline Alternative & $\frac{\text { Low CLA-R }}{\text { CLA-TT, } 14 \text { days }}$ & $\begin{array}{l}\text { Low CLA-R } \\
\text { BQT, 10-14 days } \\
\text { High CLA-R } \\
\text { ST, } 10 \text { days/CT }\end{array}$ & $\begin{array}{l}\text { BQT, 7-14 days } \\
\text { ST, } 10 \text { days } \\
\text { (need more data) }\end{array}$ & $\begin{array}{l}\text { ST, } 10 \text { days } \\
\text { (need more data }\end{array}$ \\
\hline Second-line & $\begin{array}{l}\text { BQT, } 14 \text { days } \\
\text { LEV-T, } 14 \text { days }\end{array}$ & $\begin{array}{l}\text { Low CLA-R } \\
\text { BQT, } 10-14 \text { days } \\
\text { LEV-T, } 10 \text { days } \\
\text { High CLA-R } \\
\text { LEV-T, } 10 \text { days }\end{array}$ & $\begin{array}{l}\text { BQT, } 7-14 \text { days } \\
\text { LEV-T, } 10 \text { days } \\
\text { RIF-T, } 7-10 \text { days }\end{array}$ & $\begin{array}{l}\text { BQT, } 10-14 \text { days } \\
\text { LEV-T, } 10 \text { days }\end{array}$ \\
\hline Third-line & & $\begin{array}{l}\text { Guided by antimicrobial } \\
\text { susceptibility testing }\end{array}$ & & \\
\hline
\end{tabular}

Table :. International guidelines for the management of $H$. pylori infection.

CLA-R: clarithromycin-resistant; CLA-TT: clarithromycin-containing triple therapy; BQT: bismuth-containing quadruple therapy; LEV-T:

levofloxacin-containing triple therapy; ST: sequential therapy; CT: concomitant therapy

Alternative regimens include sequential therapy (dual therapy with PPI and amoxicillin followed by triple therapy with PPI, clarithromycin and metronidazole) and quadruple therapy without bismuth compounds (concomitant therapy containing a PPI, amoxicillin, clarithromycin, and metronidazole). However, it remains challenging to these two regimens because of the rising trend in bacterial resistance to clarithromycin and metronidazole [14-16]. The failure of primary $H$. pylori therapy can then lead to substantial increase in post-treatment antimicrobial resistance $[14,17,18]$. On the other hand, levofloxacin-containing triple therapy has been recommended as the first-line, alternative, or rescue therapies [6, 13], but their eradication rates vary among studies and are usually below $90 \%$ by intention-to-treat (ITT) analysis [14]. Meanwhile, the failure of levofloxacin-containing therapy can significantly increase

\section{The Comeback of Bismuth in Treating H. pylori Infection}

Bismuth compounds have been used for over two centuries in treatment of stomatitis, bowel dysfunction (flatulence, constipation,

"Corresponding Author: Dr. Jyh-Chin Yang, Department of Internal Medicine, Hospital and College of Medicine, National Taiwan University, No. 7, ChungShan South Road, Taipei 10002, Taiwan; Tel: +886-2-937018088; E-mail: jcyang47@ntu.edu.tw

Citation: Li HM, Yang JC (2016) Bismuth-Containing Therapy for Helicobacter pylori Eradication. Int J Clin Pharmacol Pharmacother 1: 113. doi: http://dx.doi. org/10.15344/2016/ijccp/113

Copyright: @ $2016 \mathrm{Li}$ et al. This is an open-access article distributed under the terms of the Creative Commons Attribution License, which permits unrestricted use, distribution, and reproduction in any medium, provided the original author and source are credited. 
Citation: Li HM, Yang JC (2016) Bismuth-Containing Therapy for Helicobacter pylori Eradication. Int J Clin Pharmacol Pharmacother 1: 113. doi: http://dx.doi. org/10.15344/2016/ijccp/113

Page 2 of 5

abdominal pain), and non-ulcer (functional) dyspepsia [22-24]. However, the use of the majority of bismuth compounds has become unpopular because of their potential adverse effects. Also, a number of drug-regulatory authorities are actively delisting bismuth-containing products from medical use [25]. Nonetheless, the development of colloidal bismuth subcitrate (CBS), bismuth subsalicylate (BSS), and ranitidine bismuth citrate (RBC) have attracted renewed interest because of their newly discovered activities for travellers' diarrhea, peptic ulcer disease, and $H$. pylori-related gastroduodenal disease.

\section{Action Mechanism of Bismuth Salts}

Bismuth is a trivalent heavy metal element used in many medical applications [26]. A number of different bismuth-based preparations are available, including BSS that is commonly used in the United States and CBS that is used in Europe [27], and RBC. BSS is water insoluble while CBS is water soluble, and both have low systemic absorption [28]. Despite a long history of being a medicinal agent for gastrointestinal disorders and duodenal ulcers, the mechanism of action of bismuth compounds against $H$. pylori is still controversial. Nevertheless, bismuth absorption is not required for its efficacy in $H$. pylori eradication, suggesting a local mechanism for action. An effective bismuth concentration approximating $1 \mathrm{mg} / \mathrm{mL}$ has been suggested at standard therapeutic dosing [29]. The minimal inhibitory concentration of bismuth to prevent the growth of $90 \%$ of H. pylori tested (MIC90) ranges from 4 to $32 \mathrm{mg} / \mathrm{L}$ [30, 31]. Potential mechanisms of action for bismuth may include: complexes of bismuth with the bacterial wall and periplasmic membrane are noted on electron microscopic studies [32]; inhibition of a number of the enzymes produced by $H$. pylori including urease, catalase and lipase are observed, which may affect the local environment for growth of the organism [33,34]; an inhibition of adherence of $H$. pylori to surface epithelial cells can $[35,36]$; impeded proton entry into the organisms potentially impairing their ability to respond to acid and enhancing the efficacy of growth-dependent antibiotics [37].

\section{Bismuth Monotherapy and Bismuth-Containing Dual Therapy}

Starting in the mid to late 1980s, numerous studies have attempted to cure H. pylori infections using CBS, BSS, and RBC. CBS and BSS were the first bismuth compounds shown to inhibit the growth of $H$. pylori in vitro. RBS is also active against $H$. pylori in vitro [28]. However, the eradication rate of bismuth monotherapy was low and was comparable to that of amoxicillin, which mainly suppresses the organism temporarily [38-39]. Bismuth-containing treatment combined with other antibacterial agents has been more successful in treating $H$. pylori infection than with monotherapy. Eradication rate with the combination of bismuth and metronidazole was better than bismuth plus amoxicillin (55.1\% vs. $43.7 \%, \mathrm{p}=0.049)$. The average eradication rate of other dual therapies was about $48.5 \%$ (Table 2).

\section{Bismuth-Containing Triple Therapy}

Different from bismuth monotherapy and bismuth-containing dual therapy, bismuth-containing triple therapy, consisting of bismuth salt, metronidazole, and tetracycline, has been demonstrated to be effective in eradicating $H$. pylori. Giving a combination of CBS (108 $\mathrm{mg}$ four times daily) and tetracycline (500 $\mathrm{mg}$ four times daily) for 4 weeks along with metronidazole ( $200 \mathrm{mg}$ four times daily) for the first 10 days, an eradication rate of at least $94 \%$ was achieved [40, 41]. This BMT (bismuth/metronidazole/tetracycline) therapy was shown

\begin{tabular}{|c|c|c|}
\hline Antibiotic agent & Regimen & $\begin{array}{l}\text { Eradication } \\
\text { rate }(\%)\end{array}$ \\
\hline \multicolumn{3}{|c|}{ Monotherapy } \\
\hline CBS & $120 \mathrm{mg}$ QID for 4 weeks & $10 / 27(37)$ \\
\hline CBS & $120 \mathrm{mg}$ QID for 4 weeks & $2 / 26(7.7)$ \\
\hline CBS & $120 \mathrm{mg}$ QID for 4 weeks & $12 / 67(18)$ \\
\hline CBS & $120 \mathrm{mg}$ QID for 4 weeks & $14 / 43(33)$ \\
\hline CBS & $480 \mathrm{mg}$ QID for 8 weeks & $6 / 22(27)$ \\
\hline CBS & $120 \mathrm{mg}$ QID for 4 weeks & $5 / 20(25)$ \\
\hline CBS & $120 \mathrm{mg}$ QID for 4 weeks & $14 / 101(14)$ \\
\hline CBS & $120 \mathrm{mg}$ QID for 8 weeks & $6 / 20(30)$ \\
\hline CBS & $240 \mathrm{mg}$ BID for 8 weeks & $3 / 20(15)$ \\
\hline BSS & $900 \mathrm{mg}$ TID for 4 weeks & $1 / 17(5.9)$ \\
\hline BSS & $600 \mathrm{mg}$ TID for 6 weeks & $3 / 24(12)$ \\
\hline Amoxicillin & $375 \mathrm{mg}$ TID for 4 weeks & $5 / 22(23)$ \\
\hline Amoxicillin & $750 \mathrm{mg}$ BID for 2 weeks & $1 / 7(14)$ \\
\hline Amoxicillin & $375 \mathrm{mg}$ TID for 4 weeks & $11 / 45(24)$ \\
\hline Doxycycline & $100 \mathrm{mg}$ QD for 9 days & $0 / 7(0)$ \\
\hline Tinidazole & $1 \mathrm{~g}$ BID for 5 days & $0 / 7(0)$ \\
\hline \multicolumn{3}{|c|}{ Dual therapy } \\
\hline CBS + Amoxicillin & $\begin{array}{l}120 \mathrm{mg} \text { QID for } 4 \text { week }+ \\
375 \mathrm{mg} \text { TID for } 4 \text { week }\end{array}$ & $8 / 20(40)$ \\
\hline CBS + Amoxicillin & $\begin{array}{l}120 \mathrm{mg} \text { QID for } 4 \text { week + } \\
500 \mathrm{mg} \text { TID for } 1 \text { week }\end{array}$ & $9 / 18(50)$ \\
\hline CBS + Amoxicillin & $\begin{array}{l}120 \mathrm{mg} \text { QID for } 4 \text { week + } \\
500 \mathrm{mg} \text { TID for } 2 \text { week }\end{array}$ & $12 / 60(60)$ \\
\hline CBS + Amoxicillin & $\begin{array}{l}120 \mathrm{mg} \text { QID for } 2 \text { week }+ \\
500 \mathrm{mg} \text { TID for } 1 \text { week }\end{array}$ & $10 / 20(50)$ \\
\hline CBS + Amoxicillin & $\begin{array}{l}120 \mathrm{mg} \text { QID for } 4 \text { week + } \\
375 \mathrm{mg} \text { TID for } 4 \text { week }\end{array}$ & $8 / 23(35)$ \\
\hline BSS + Amoxicillin & $\begin{array}{l}600 \mathrm{mg} \text { TID for } 6 \text { week }+1 \\
\mathrm{~g} \text { BID for } 2 \text { week }\end{array}$ & $11 / 23(49)$ \\
\hline CBS + Metronidazole & $\begin{array}{l}120 \mathrm{mg} \text { QID for } 4 \text { week }+ \\
400 \mathrm{mg} \text { TID for } 1 \text { st week }\end{array}$ & $19 / 26(73)$ \\
\hline CBS + Metronidazole & $\begin{array}{l}120 \mathrm{mg} \text { QID for } 1 \text { week + } \\
500 \mathrm{mg} \text { TID for } 1 \text { week }\end{array}$ & $10 / 26(38)$ \\
\hline BSS + Metronidazole & $\begin{array}{l}524 \mathrm{mg} \text { QID for } 3 \text { week }+ \\
250 \mathrm{mg} \text { QID for } 2 \text { week }\end{array}$ & $15 / 19(79)$ \\
\hline $\begin{array}{l}\text { Amoxicillin }+ \\
\text { Metronidazole }\end{array}$ & $\begin{array}{l}500 \mathrm{mg} \text { TID for } 1 \text { week }+ \\
400 \mathrm{mg} \text { TID for } 1 \text { week }\end{array}$ & $15 / 27(56)$ \\
\hline $\begin{array}{l}\text { Amoxicillin }+ \\
\text { Tinidazole }\end{array}$ & $\begin{array}{l}500 \mathrm{mg} \text { QID for } 8 \text { days }+ \\
200 \mathrm{mg} \text { BID for } 8 \text { days }\end{array}$ & $28 / 53(53)$ \\
\hline $\begin{array}{l}\text { Amoxicillin + } \\
\text { Ofloxacin }\end{array}$ & $\begin{array}{l}500 \mathrm{mg} \text { QID for } 8 \text { days }+ \\
200 \mathrm{mg} \text { BID for } 8 \text { days }\end{array}$ & $3 / 15(20)$ \\
\hline
\end{tabular}

Table 2: Monotherapy and dual therapy used in the treatment of $H$. pylori infection.

to give a statistically higher eradication rate than the combination of bismuth, metronidazole, and amoxicillin $(94.1 \%$ vs. $73.1 \%, \mathrm{p}<0.0005)$ [39]. In this regard, the BMT therapy has been recommended at the NIH Consensus Conference on H. pylori in 1994 [42]. However, metronidazole resistance significantly reduced the effectiveness of the regimen. The eradication rate was $19 / 21(90.5 \%)$ in patients with metronidazole-sensitive organisms, whereas it was only $6 / 19(31.6 \%)$ 
Citation: Li HM, Yang JC (2016) Bismuth-Containing Therapy for Helicobacter pylori Eradication. Int J Clin Pharmacol Pharmacother 1: 113. doi: http://dx.doi. org/10.15344/2016/ijccp/113

Page 3 of 5

in patients with metronidazole-resistant strains [43]. Also, the complexity of these regimens has led to poor patient compliance in clinical practice. In this regard, BMT therapy was gradually replaced by the clarithromycin-containing triple therapy.

\section{Bismuth-Containing Quadruple Therapy}

Although bismuth-containing triple therapy provides high eradication rates, primary and acquired resistance to metronidazole in $H$. pylori has led to treatment failure [44,45]. In early 1990s, proton pump inhibitors (PPIs) were developed and have been concomitantly used with bismuth-containing triple therapy, showing increased treatment efficacy $[46,47]$. The combination had its supporters but remained a rescue treatment thereafter before the PPI-clarithromycincontaining triple therapy was recommended as the standard treatment $[48,49]$. However, the effectiveness of PPI-clarithromycin-containing triple therapy is decreasing due to the increase in antibiotic resistance to clarithromycin. Alternatively, bismuth-containing quadruple therapy (BQT) containing a PPI, bismuth, metronidazole, and tetracycline is effective even in the presence of resistance to metronidazole [50]. For the comparison of BQT and standard triple therapy, BQT achieved eradication in $83.4 \%$ of patients whereas standard triple therapy achieved an eradication rate of $70.4 \%[51,52]$. There were no statistical differences in side effect and compliance. Starting from Maastricht III consensus report, in areas with high clarithromycin resistance, BQT is recommended instead of standard triple therapy as alternative first choice treatment for $H$. pylori eradication [53]. Currently, not only in Europe but in Toronto Consensus, BQT consisting of a PPI, bismuth, metronidazole, and tetracycline for 10-14 days has been recommended to be the standard or an alternative first-line treatment in areas with $15-20 \%$ prevalence of clarithromycin resistance $[6,54]$. Also, BQT can eradicate the bacterium in $77.6 \%$ (range from $64.8 \%$ to $89.4 \%$ ) of naïve patient by ITT analysis and its efficacy was not affected by metronidazole resistance [55]. However, it was difficult to get a good compliance because of the difference in the timetable of each medicine and the problems to get the bismuth salts in some countries. The development of a formulation of BMT three-in-one capsule (Pylera ${ }^{\circ}$, Aptalis, Mont St Hilaire, QC, Canada) may allow standardization of the treatment with a better compliance [52]. The combined formulation has shown to be effective in the treatment of $H$. pylori infection [56]. However, photosensitivity has been a major concern, which can be manifested by an exaggerated sunburn reaction in patients taking tetracycline. Bismuth subcitrate potassium may cause temporary and harmless darkening of the tongue and/or black stools, generally reversible within several days after treatment is stopped. Other adverse reactions include taste perversion, diarrhea, nausea, headache, and abdominal pain [57].

The comeback of BQT because it has the advantage of using the following compounds. First, the resistance of bismuth salts have not been described. Secondly, tetracycline is an antibiotic for which resistance is rarely encountered. The reason is that to reach a high level resistance, three adjacent point mutations are required. The change in the nucleotide triplet (AGA-926 to $928 \rightarrow$ TTC) has been associated with this resistance probably because of a lack of binding to the h1 loop, which is the binding site of tetracycline on the $30 \mathrm{~S}$ subunit of the ribosome. For the third antimicrobial compound, metronidazole, it against $H$. pylori is also concentration-dependent [58,59]. Also, it has a post-antibiotic effect for more than 3 hours against anaerobes, but there is no available data against $H$. pylori [60]. Resistance in vitro exists at a high prevalence in most countries around the world, but the clinical impact of this resistance is limited and it can be overcome by increasing the dose and duration of treatment.

\section{Prolong Treatment Duration to 14 Days}

In light of the higher eradication rates compared to regimens of shorter durations, the consensus group strongly recommended that all $H$. pylori regimens (both first-line and rescue therapies) be administered for 14 days. This prolonged use of antibiotics for all patients is warranted because the increased failure with shorter regimens would result in resistant strains and less successful future treatments. It is best to achieve the maximum cure rates from the start [54].

\section{Conclusion}

The resistance to clarithromycin and metronidazole has limited the application of standard triple therapy. As the resistance to bismuth has not been reported, bismuth-containing therapy is worth an attention and BQT is currently a better bismuth-containing therapy used in the treatment of $H$. pylori infection. BQT has been recommended as an alternative first choice regimen to standard triple therapy, in areas with low clarithromycin resistance, and it is recommended as the first-line therapeutic option in areas with a high prevalence of clarithromycin resistance. Although the $\mathrm{BQT}$ is limited by the complex dosing schedule and side-effects, a formulation of BMT three-in-one capsule can be helpful to overcome this problem.

\section{Competing Interest}

The authors declare that they have no competing ointerests.

\section{References}

1. Marshall BJ, Warren JR (1984) Unidentified curved bacilli in the stomach of patients with gastritis and peptic ulceration. Lancet 1: 1311-1315.

2. Suerbaum S, Michetti $P(2002)$ Helicobacter pylori infection. N Engl J Med 347: 1175-1186.

3. Malfertheiner P, Chan FK, McColl KE (2009) Peptic ulcer disease. Lancet 374: 1449-1461.

4. Chey WD, Wong BC; Practice Parameters Committee of the American College of Gastroenterology (2007) American College of Gastroenterology guideline on the management of Helicobacter pylori infection.Am J Gastroenterol 102: 1808-1825.

5. Fock KM, Katelaris P, Sugano K, Ang TL, Hunt R, et al. (2009) Second Asia-Pacific Consensus Guidelines for Helicobacter pylori infection.J Gastroenterol Hepatol 24: 1587-1600.

6. Malfertheiner P, Megraud F, O'Morain CA, Atherton J, Axon AT, et al. (2012) Management of Helicobacter pylori infection--the Maastricht IV/ Florence Consensus Report. Gut 61: 646-664.

7. Dore MP, Leandro G, Realdi G, Sepulveda AR, Graham DY (2000) Effect of pretreatment antibiotic resistance to metronidazole and clarithromycin on outcome of Helicobacter pylori therapy: a meta-analytical approach. Dig Dis Sci 45: 68-76.

8. Mégraud F (2004) H pylori antibiotic resistance: prevalence, importance, and advances in testing. Gut 53: 1374-1384.

9. Megraud F, Coenen S, Versporten A, Kist M, Lopez-Brea M, et al. (2013) Helicobacter pylori resistance to antibiotics in Europe and its relationship to antibiotic consumption. Gut 62: 34-42.

10. Wolle K, Leodolter A, Malfertheiner P, König W (2002) Antibiotic susceptibility of Helicobacter pylori in Germany: stable primary resistance from 1995 to 2000. J Med Microbiol 51: 705-709.

11. Torres J, Camorlinga-Ponce M, Pérez-Pérez G, Madrazo-De la Garza A Dehesa M, et al. (2001) Increasing multidrug resistance in Helicobacter pylori strains isolated from children and adults in Mexico. J Clin Microbiol 39: $2677-2680$ 
Citation: Li HM, Yang JC (2016) Bismuth-Containing Therapy for Helicobacter pylori Eradication. Int J Clin Pharmacol Pharmacother 1: 113. doi: http://dx.doi. org/10.15344/2016/ijccp/113

Page 4 of 5

12. Perez Aldana L, Kato M, Nakagawa S, Kawarasaki M, Nagasako T, et al (2002) The relationship between consumption of antimicrobial agents and the prevalence of primary Helicobacter pylori resistance. Helicobacter 7 : 306-309.

13. Graham DY, Fischbach $L$ (2010) Helicobacter pylori treatment in the era of increasing antibiotic resistance.Gut 59: 1143-1153.

14. Vakil N, Vaira D (2013) Treatment for H. pylori infection: new challenges with antimicrobial resistance.J Clin Gastroenterol 47: 383-388.

15. Rimbara E, Fischbach LA, Graham DY (2011) Optimal therapy for Helicobacter pylori infections.Nat Rev Gastroenterol Hepatol 8: 79-88.

16. Graham DY, Lee YC, Wu MS (2014) Rational Helicobacter pylori therapy: evidence-based medicine rather than medicine-based evidence. Clin Gastroenterol Hepatol 12: 177-186.

17. Heep M, Kist M, Strobel S, Beck D, Lehn N (2000) Secondary resistance among 554 isolates of Helicobacter pylori after failure of therapy. Eur J Clin Microbiol Infect Dis 19: 538-541.

18. Peitz U, Sulliga M, Wolle K, Leodolter A, Von Arnim U, et al. (2002) High rate of post-therapeutic resistance after failure of macrolide-nitroimidazole triple therapy to cure helicobacter pylori infection: Impact of two secondline therapies in a randomized study. Aliment Pharmacol Ther 16: 315-324

19. Yang JC, Lin CJ, Wang HL, Chen JD, Kao JY, et al. (2015) High-dose dua therapy is superior to standard first-line or rescue therapy for Helicobacter pylori infection.Clin Gastroenterol Hepatol 13: 895-905.

20. Gerrits MM, van Vliet AH, Kuipers EJ, Kusters JG (2006) Helicobacte pylori and antimicrobial resistance: molecular mechanisms and clinical implications.Lancet Infect Dis 6: 699-709.

21. Camargo MC, García A, Riquelme A, Otero W, Camargo CA, et al. (2014) The problem of Helicobacter pylori resistance to antibiotics: a systematic review in Latin America. Am J Gastroenterol 109: 485-495.

22. Marshall BJ, Valenzuela JE, McCallum RW, Dooley CP, Guerrant RL, et al (1993) Bismuth subsalicylate suppression of helicobacterpylori in nonulcer dyspepsia: A double-blind placebo-controlled trial. Dig Dis Sci 38:16741680.

23. Konturek SJ, Radecki T, Piastucki I, Drozdowicz D (1986) Advances in the understanding of the mechanism of cytoprotective action by colloidal bismuth subcitrate.Scand J Gastroenterol Suppl 122: 6-10.

24. Lambert JR (1991) Clinical indications and efficacy of colloidal bismuth subcitrate. Scand J Gastroenterol Suppl 185: 13-21.

25. Bradley B, Singleton M, Lin Wan Po A (1989) Bismuth toxicity--a reassessment. J Clin Pharm Ther 14: 423-441.

26. Mohan R (2010) Green bismuth. Nat Chem 2: 336.

27. Scarpignato C, Pelosini I (1999) Bismuth compounds for eradication of helicobacter pylori: Pharmacology and safety. Clinical Pharmacology and Therapy of Helicobacter pylori Infection Prog Basic Clin Pharmacol Basel, Switzerland: Karger 11:87-127.

28. Lambert JR, Midolo $P$ (1997) The actions of bismuth in the treatment of Helicobacter pylori infection. Aliment Pharmacol Ther 11 Suppl 1: 27-33.

29. Stratton CW, Warner RR, Coudron PE, Lilly NA (1999) Bismuth-mediated disruption of the glycocalyx-cell wall of Helicobacter pylori: ultrastructural evidence for a mechanism of action for bismuth salts. J Antimicrob Chemother 43: 659-666.

30. Lambert JR, Hanksky J, Davidson A, Pinkard K, Stockman K (1985) Campylobacter like organisms (clo) in vivo and in vitro susceptibility to antimicrobial and antiulcer therapy. Gastroenterology 88:1462.

31. Andreasen JJ, Andersen LP (1987) In vitro susceptibility of Campylobacter pyloridis to cimetidine, sucralfate, bismuth and sixteen antibiotics. Acta Pathol Microbiol Immunol Scand B 95: 147-149.

32. Armstrong JA, Wee SH, Goodwin CS, Wilson DH (1987) Response of Campylobacter pyloridis to antibiotics, bismuth and an acid-reducing agent in vitro--an ultrastructural study. J Med Microbiol 24: 343-350.

33. Slomiany BL, Kasinathan C, Slomiany A (1989) Lipolytic activity of Campylobacter pylori: effect of colloidal bismuth subcitrate (De-Nol). Am J Gastroenterol 84: 1273-1277.

34. Nilius M, Ströhle A, Bode G, Malfertheiner P (1993) Coccoid like forms (CLF) of Helicobacter pylori. Enzyme activity and antigenicity. Zentralbl Bakteriol 280: 259-272.
35. Goodwin CS, Armstrong JA, Cooper M. (1991) Colloidal bismuth subcitrate inhibits the adherence of h. Pylori to epithelial cells. Ital J Gastroenterol (suppl 2) 23:40.

36. Nilius M, Schieffer S, Malfertheiner P (1992) Inhibition of h. Pylori adhesion to human smc by cbs and different proteaases. Ir J Med Sci (Suppl 10) 161:10.

37. Marcus EA, Sachs G, et al. (2015) Colloidal bismuth subcitrate impedes proton entry into Helicobacter pylori and increases the efficacy of growthdependent antibiotics. Aliment Pharmacol Ther 42: 922-933.

38. Marshall BJ, Armstrong JA, Francis GJ, Nokes NT, Wee SH (1987) Antibacterial action of bismuth in relation to Campylobacter pyloridis colonization and gastritis. Digestion 37 Suppl 2: 16-30.

39. Chiba N, Rao BV, Rademaker JW, Hunt RH (1992) Meta-analysis of the efficacy of antibiotic therapy in eradicating Helicobacter pylori. Am J Gastroenterol 87: 1716-1727.

40. George LL, Borody TJ, Andrews P, Devine M, Moore-Jones D, et al. (1990) Cure of duodenal ulcer after eradication of Helicobacter pylori. Med J Aust 153: 145-149.

41. Borody TJ, Cole P, Noonan S, Morgan A, Lenne J, et al. (1989) Recurrence of duodenal ulcer and Campylobacter pylori infection after eradication. Med J Aust 151: 431-435.

42. [No authors listed](1994) NIH Consensus Conference. Helicobacter pylori in peptic ulcer disease. NIH Consensus Development Panel on Helicobacter pylori in Peptic Ulcer Disease. JAMA 272: 65-69.

43. Bell GD, Powell K, Burridge SM, Pallecaros A, Jones PH, et al. (1992) Experience with 'triple' anti-Helicobacter pylori eradication therapy: side effects and the importance of testing the pre-treatment bacterial isolate for metronidazole resistance. Aliment Pharmacol Ther 6: 427-435.

44. Rautelin H, Seppälä K, Renkonen OV, Vainio U, Kosunen TU (1992) Role of metronidazole resistance in therapy of Helicobacter pylori infections. Antimicrob Agents Chemother 36: 163-166.

45. Glupczynski Y, Burette A, De Koster E, Nyst JF, Deltenre M, et al. (1990) Metronidazole resistance in Helicobacter pylori. Lancet 335: 976-977.

46. Hosking SW, Ling TK, Yung MY, Cheng A, Chung SC, et al. (1992) Randomised controlled trial of short term treatment to eradicate Helicobacter pylori in patients with duodenal ulcer. BMJ 305: 502-504.

47. de Boer W, Driessen W, Jansz A, Tytgat G (1995) Effect of acid suppression on efficacy of treatment for Helicobacter pylori infection. Lancet 345: 817820.

48. Group EHPS (1997) Current european concepts in the management of helicobacter pylori infection. The maastricht consensus report. Gut 41: 8-13.

49. Malfertheiner P, Mégraud F, O'Morain C, Hungin AP, Jones R, et al. (2002) Current concepts in the management of Helicobacter pylori infection--the Maastricht 2-2000 Consensus Report. Aliment Pharmacol Ther 16: 167180.

50. Fischbach LA, van Zanten S, Dickason J (2004) Meta-analysis: the efficacy, adverse events, and adherence related to first-line anti-Helicobacter pylori quadruple therapies. Aliment Pharmacol Ther 20: 1071-1082.

51. Laine L, Hunt R, El-Zimaity H, Nguyen B, Osato M, et al. (2003) Bismuthbased quadruple therapy using a single capsule of bismuth biskalcitrate, metronidazole, and tetracycline given with omeprazole versus omeprazole, amoxicillin, and clarithromycin for eradication of Helicobacter pylori in duodenal ulcer patients: a prospective, randomized, multicenter, North American trial. Am J Gastroenterol 98: 562-567.

52. Malfertheiner P, Bazzoli F, Delchier JC, Celinski K, Giquère M, et al. (2011) Helicobacter pylori eradication with a capsule containing bismuth subcitrate potassium, metronidazole, and tetracycline given with omeprazole versus clarithromycin-based triple therapy: A randomised, open-label, noninferiority, phase 3 trial. Lancet 377: 905-913

53. Malfertheiner P, Megraud F, O'Morain C, Bazzoli F, El-Omar E, et al. (2007) Current concepts in the management of Helicobacter pylori infection: the Maastricht III Consensus Report. Gut 56: 772-781. 
Citation: Li HM, Yang JC (2016) Bismuth-Containing Therapy for Helicobacter pylori Eradication. Int J Clin Pharmacol Pharmacother 1: 113. doi: http://dx.doi. org/10.15344/2016/ijccp/113

Page 5 of 5

54. Fallone CA, Chiba N, van Zanten SV, Fischbach L, Gisbert JP5, et al. (2016) The Toronto Consensus for the Treatment of Helicobacter pylori Infection in Adults. Gastroenterology 151: 51-69.

55. Venerito M, Krieger T, Ecker T, Leandro G, Malfertheiner P (2013) Metaanalysis of bismuth quadruple therapy versus clarithromycin triple therapy for empiric primary treatment of Helicobacter pylori infection. Digestion 88: 33-45.

56. Delchier JC, Malfertheiner P, Thieroff-Ekerdt R (2014) Use of a combination formulation of bismuth, metronidazole and tetracycline with omeprazole as a rescue therapy for eradication of Helicobacter pylori. Aliment Pharmacol Ther 40: 171-177.

57. O'Morain C, Borody T, Farley A, De Boer WA, Dallaire C, et al. (2003) Efficacy and safety of single-triple capsules of bismuth biskalcitrate, metronidazole and tetracycline, given with omeprazole, for the eradication of Helicobacter pylori: an international multicentre study. Aliment Pharmacol Ther 17: 415-420.

58. Irie Y, Tateda K, Matsumoto T, Miyazaki S, Yamaguchi K (1997) Antibiotic MICs and short time-killing against Helicobacter pylori: therapeutic potential of kanamycin. J Antimicrob Chemother 40: 235-240.

59. Hoffman PS, Goodwin A, Johnsen J, Magee K, Veldhuyzen van Zanten SJ (1996) Metabolic activities of metronidazole-sensitive and -resistant strains of Helicobacter pylori: repression of pyruvate oxidoreductase and expression of isocitrate lyase activity correlate with resistance. J Bacteriol 178: $4822-4829$

60. Lamp KC, Freeman CD, Klutman NE, Lacy MK (1999) Pharmacokinetics and pharmacodynamics of the nitroimidazole antimicrobials. Clin Pharmacokinet 36: 353-373. 